\title{
FISHERIES SERVICE PORT (Study of Public Services in the Technical Implementation Unit Pondokdadap Coastal Fisheries Port, East Java Province)
}

\author{
Budi Santoso \\ Student of Doctor Study Program of Administration Sciences - FISIP, Universitas 17 Agustus 1945 Surabaya, \\ J1. Semolowaru No. 45 Surabaya, Jawa Timur, Indonesia
}

Agus Sukristyanto

\begin{abstract}
Zakariya
Abstract

This research aims to review public services at the Technical Implementation Unit of the Pondokdadap Coastal Fisheries Port, explain the factors that lead to unprofessional and quality public services and to find models of professional and quality public services in the Technical Implementation Unit. The approach used in this research is qualitative research with a case study design. Data collection techniques used were observation, interviews, and documentation. This study uses descriptive qualitative data analysis techniques and uses data analysis consisting of 3 stages, namely data reduction, data presentation, and drawing conclusions or data verification. Data analysis techniques in this study used the inductive logic approach. The results showed that the service at the Technical Implementation Unit of the Pondokdadap Coastal Fisheries Port was able to meet the needs of the community, but not yet optimal. This is influenced by the lack of numbers and professionalism of human resources, the model of services that are less than the maximum and the limited facilities available. A professional and quality public service model can be supported by applying stop a one-service model that is supported by adequate facilities, professional and moral human resources as well as an effective, efficient and modern governance system and adopts the concept of the organizational governance system of the Regional Public Service Board (BLUD).
\end{abstract}

Keywords: Services, Ports, Fisheries

DOI: $10.7176 /$ PPAR/10-7-03

Publication date:July $31^{\text {st }} 2020$

\section{BACKGROUND}

The current work spirit of the Indonesian Government with a vision of realizing an independent, independent and personality based on the principle of mutual cooperation. The state will always be present during society to build clean, effective, democratic and reliable governance that is the breath of bureaucratic reform. This vision is elaborated in a mental revolution directed at restoring the identity of the Indonesian bureaucracy from boss mentality to serving bureaucracy, manifested by a change of mindset, bureaucratic work culture and structuring the government bureaucratic structure that has been less agile in responding to social change in society. This mental revolutionary movement is expected to realize the vision of bureaucratic reform, namely the realization of a worldclass government in 2025, and to deliver the Indonesian nation to become a competitive nation capable of competing in the ASEAN arena.

A world-class government that has competitiveness requires a strong and advanced economic foundation. The Indonesian economy will advance and develop rapidly by prioritizing the economy of the maritime sector, considering that $70 \%$ of Indonesia's territory is water. The development of the maritime sector covers the field of maritime production and distribution, so the development of the production sector and maritime distribution must begin with bureaucratic reform in the form of building a clean, professional maritime bureaucracy that can provide professional and quality services to the community. Fisheries port is a state apparatus that has a governmental and commercial function by organizing public services in the marine and fisheries sector. The implementation is carried out by the movement of mental revolution bureaucracy port fishery that includes 3 steps transformative, namely: 1) changing the paradigm (mindset) of bureaucratic gentry to bureaucracy airport, from bureaucracy oriented to the output to bureaucracy oriented to results (outcomes) and benefits; 2) change the work(culture set) of bureaucracy, from a slow, convoluted, less competent, wasteful, sectoral and corrupt work culture to a work culture that is fast, simple, competent, economical, works across sectors and clean; and 3) structuring the management structure of the government bureaucracy which has been less agile in responding to people's expectations, as well as the flow of social, cultural, economic and political change as a result of globalization.

The existence of a fishing port needs special attention in efforts to develop capture fisheries. The existence of a large number of fishing ports also causes problems for the government. The main problems are management after the fishing port has been built, including operation, maintenance, rehabilitation and service of infrastructure facilities. If the management is not carried out properly, it will be an obstacle to the realization of the function and 
role of the fishing port as stated in the Regulation of the Minister of Maritime Affairs and Fisheries of the Republic of Indonesia Number Regulation.08/Men/2012 concerning Fisheries Port, that the fishing port plays an important role in the implementation of fishing surveillance and source control fish power and quality control of fishery products, especially capture fisheries.

The Pondokdadap Coastal Fisheries Port Technical Implementation Unit (UPT PPP Pondokdadap), is one of the fisheries port organizations in Indonesia which is being developed by the East Java government towards the realization of Sendang Biru Minapolitan City. As a megapolitan city, the role of a fisheries port will be the cornerstone of operational activities in encouraging activities of daily activities. These activities not only serve fishing vessels but also as a driving force in other activities related to the management of marine resources such as economy, sea transportation, marine tourism, workshop, maritime industry and trade and other government administrator activities.

UPT PPP Pondokdadap has a major contribution to development in East Java Province, especially the economic drivers of the local community. The contribution of the fishing business can be seen from the financial round that was carried out at the Sendang Biru Fish Auction (TPI) which reached Rp. 78,892,120,000 in 2016. Revenue from port facility levies in 2016 reached Rp. 250,094,384 from the PAD target of Rp. 200,000,000. Not to mention the activities of other sectors such as fishing logistics, fuel, ice cubes, workshop, spare parts and other fishermen's needs. (Pondokdadap Coastal Fisheries Port: 2019)

Regulation of the Minister of Maritime Affairs and Fisheries Number. 08/Men/2012, is a policy reference for the management of Fisheries Port towards the realization of Sendang Biru Minapolitan City. However, in the process of implementing the policy, there were still several problems relating to the port authority, particularly public services to the public who use goods, services and port administration services. Factors of infrastructure readiness, bureaucratic systems, human resources and service mechanisms are still a matter of public service at UPT PPP Pondokdadap.

Some obstacles faced are organizational resources, infrastructure, and higher authority in East Java Province. The fishing vessel document policy is a problem for fishermen in Pondokdadap, so there are many vessels which do not meet the complete fishing document. This has become an obstacle to the achievement of the vision and mission of developing a fishing port as a technical operational unit for fishing vessel operations in its area. Data in 2018 shows that of the 434 ships operating in Pondokdadap, only 115 ships were equipped with documents, meaning that only $26.5 \%$ of the ships had complete documents. This data is an indicator that administrative services at the UPD of the Pondokdadap Beach Fishery Port still need attention.

On the other hand, fisheries port administrators have tried to provide maximum services so that capture fisheries business operators in Pondokdadap can complete ship documents correctly. Time constraints, cost and length of bureaucracy often become a limitation in organizing the administration of fishing vessel documents and fishing permits. Interrupted two-way communication can lead to different perceptions in solving a problem with fishing vessel documents.

This fact also shows that the legal awareness of the capture fisheries business community as service consumers in Pondokdadap has not yet been achieved. They have not yet realized the importance of completing ship and fishing documents as well as administration of catching fish. Policy socialization by the administrator implementing fisheries port policy has not reached the target, so the fisheries port development goals have not been able to be realized as expected.

Logistical needs at the base during the fishing preparation process are not always available. The support of fuel and ice cubes depends on the shipment and allotment determined by the cooperative and the private sector. Port fisheries are still not able to do their procurement because raw material needs are not yet available. Moreover, the strength of electric power from the State Electricity Company (PLN) for the port area is only capable of lighting and routine port operations.

The social and cultural conditions of the local community also directly influence the demands of needs. The social paradigm in the contemporary era which began to shift as a result of the influence of global media often causes perversion in describing the rules set by the government. The condition of society, which is a socio-cultural phenomenon of contemporary (contemporary) also affects the level of service needs. The blurring of boundaries between community needs and the availability of public service infrastructure often creates new problems in the delivery of services at fishing ports. The changing paradigm of a neo-capitalist democratic society has changed the life order of the people by involving the community in the administration of government.

This fishery port public service is the most important current issue to discuss because the operational of UPT PPP Pondokdadap is considered urgent in meeting public needs. The issue of port authority becomes dominant, in providing services to the community to carry out government functions, and the business function to improve public services. The two UPT PPP Pondokdadap functions are carried out in the form of public services. As a government apparatus organizes government administrative services and in the business function organizes public goods and services.

Observing this phenomenon, researchers feel this problem needs to be studied and solved. The researcher 
intends to examine public services in the Technical Implementation Unit of the Pondokdadap Coastal Fisheries Port of East Java Province. Researchers will examine the factors that influence the phenomena that occur at the fishery port from fishery port public services. Among them is the level of availability of organizational resource facilities and strategies and models of public services based on fisheries port policy. The results of this study are expected to be able to analyze the existing problems and find solutions by the current situation and conditions encountered and can improve the performance of the administrator of the Pondokdadap Coastal Fisheries Technical Implementation Unit, and be beneficial for the public service delivery of the Indonesian Fishery Port Technical Implementation Unit in the future.

\section{METHOD}

The approach used in this research is qualitative research. The design used is a case study because researchers carefully investigate an event, activity, and process of the object under study. In this study, researchers sought to know, understand, and appreciate the implementation of Public Services in the Technical Implementation Unit of the Pondokdadap Coastal Fisheries Port of East Java Province. This research was conducted at the Port of the Coastal Fisheries of Pondokdadap, East Java Province, which is located in Sendang Biru Hamlet, Tambakrejo Village, Sumbermanjing Wetan District, Malang Regency, East Java Province, in the position of LS $8^{0} 28$ 'BT $112^{0} 40^{\prime}$.

Data that will be collected by researchers in the form of physical, written, activity, and verbal data from the data source, in this case, all port components, namely the Head of the Port, Head of Operational Section, Head of the Supervision Section of the UPD Port of Fisheries at Pondokdadap Beach, KUD Mina Jaya Sendang Biru, The Commander of the Sendang Biru Navy Navy Post, Head of the Regional Port Management Unit of the Malang Regency Fisheries Marine Resources Management, Chairman of the Adi Karya Fish Traders Association in Sendang Biru TPI, Chairperson of Sendang Biru HNSI and other sources of information that understand the problem.

Data collection methods carried out by researchers, namely: documentation, interviews, and observation. Data to be collected in the form of physical, written, activity and oral data. Physical data were obtained through participatory observation techniques and in-depth interviews. Written data obtained through documentation techniques. Activity data is obtained through participatory observation, documentation, and aided by field notes. Oral data, obtained through in-depth interview techniques on research subjects related to the focus of research. This study uses descriptive qualitative data analysis techniques and uses data analysis consisting of 3 stages, namely data reduction, data presentation, and drawing conclusions or data verification. Data analysis techniques in this study used the inductive logic approach.

\section{RESULTS}

\subsection{Public Service at the Technical Implementation Unit of Pondokdadap Beach Fishery Port}

UPT PPP Pondokdadap included in Port Class C Fisheries With the criteria: (1) able to serve fishing vessels that conduct fishing activities in Indonesian waters, (2) has mooring facilities for fishing vessels of the size of at least - at least $10 \mathrm{GT}$, and (3) jetty length of at least $100 \mathrm{~m}$ with pond depth of at least minus $2 \mathrm{~m}$, and (4) able to accommodate fishing vessels of at least 30 units or a total of at least $300 \mathrm{GT}$. The quality is supported by having infrastructure facilities in the form of facilities that have met the criteria that must be owned by a fishing port in carrying out service activities and this UPT is the only representative of a fishing port in East Java Province as a national fishery centre area. This is evidenced by the results of fish production at the Pondokdadap Fishery Port which has reached 8,299,267 $\mathrm{kg}$ up to November 5,2018, with around 16\% of its production, which is $1,404,341$ $\mathrm{kg}$, which is tuna which is the leading fishery product in the PPP area Pondokdadap.

UPT PPP Pondokdadap also conducts public services of goods and services. The level of service operations performed is strongly influenced by the facilities they have named, (1) basic, functional and supporting facilities. The main facilities owned by UPT PPP Pondokdadap are complete and meet the criteria, namely, (1) Port area of 8.26 hectares out of a minimum of 5 hectares required for fishermen to unload fish and load provisions, (2) Port Pond for spinning ships, waiting a turn to lean on the dock, rest, or to wait for the turn of the next fishing trip departure, (3) Landing dock used to unload fish catches from shaped fishing boat pier- and pier Equipment used for refuelling and loading of supplies needed by ships for fishing such as water, ice, etc., (4) roads harbour complex with a length of $1900 \mathrm{~m}$ is equipped with drainage, plaster / plengsengan with an area of $1,900 \mathrm{~m}^{2}$ and the road leading to the new TPI along $1,600 \mathrm{~m}$. The basic facilities are supported by functional and supporting facilities.

Functional facilities UPD PPP Pondokdadap consists of, (1) Main Office Building with an area of $329.5 \mathrm{~m}^{2}$, (2) Old Fish Auction Place (TPI) building with an area of $720 \mathrm{~m}^{2}$, (3) New TPI Building with an area of 1,200 $\mathrm{m}^{2}$, (4) Area parking of vehicles at the port with an area of 2,000 $\mathrm{m}^{2},(5)$ Warehouse salt with an area of $204 \mathrm{~m}^{2},(6)$ water reservoir with an area of $16 \mathrm{~m}^{2}$, (7) Tandon new water with an area of $20 \mathrm{~m}^{2},(8)$ tank of diesel and dispenser 1 unit, (9) Building genset with an area of $60 \mathrm{~m}^{2}$, (10) Genset capacity of 65 KVA 2 units, (11) Building old forge with an area of $60 \mathrm{~m}^{2},(12)$ building a new workshop with an area of $180 \mathrm{~m}^{2}$, (13) Old Fishermen Meeting Hall 
with an area of $130 \mathrm{~m}^{2}$, (14) New Fishermen Meeting Hall with an area of $150 \mathrm{~m}^{2}$, (15) Cold Storage with an area of $200 \mathrm{~m}^{2}$ and Integrated Cold Storage capacity of 100 tons, (16) Toilets building with an area of $60 \mathrm{~m}^{2},(17)$ fence BRC perimeter, (18) 1 unit of SSB Radio, (19) 3 units of scavenging buildings, (20) 7 units of fresh fish, and (21) Mess Fishermen 8 units, (22) The marketing of fish spacious with an area of 1,200 $\mathrm{m}^{2}$, (23) Building Processing area of 1,200 $\mathrm{m}^{2},(24)$ Disposal While as many as 1 unit, (25) Kiosk Fish fisherman with a capacity of 60 kiosks, and (26) 2 units of WWTP.

Supporting Facilities UPT PPP Pondokdadap indirectly increased the role of the port, namely: (1) Guest House "Wisma Madidihang" with a capacity of 17 rooms, (2) Shelter "Wisma Albakor" with a capacity of 68 people, (3) Guard Post with an area of $16 \mathrm{~m}^{2}$, (4) Meeting Hall with an area of $130 \mathrm{~m}^{2}$,(5) Musholla with an area of $100 \mathrm{~m}^{2}$, (6) PASTI monument (highest post) of 1 unit, and (7) Public toilet.

With its existing functional and supporting facilities, UPT PPP Pondokdadap can carry out its main functions as a fishing port, such as providing mooring services, loading and unloading, repair and supplies of fishing vessels, processing services, marketing, and distribution of fish, as well as service utilization facilities and land. UPT PPP Pondokdadap also innovates to develop potential in the region with the concept of an eco fishing port, namely the concept of developing an environmentally friendly fishing port. Other services provided at UPT PPP Pondokdadap are administrative services. The types of services are as follows, (1) the management of a Fish Landing Certificate, (2) The function of harnessing at the Fishery Port for the achievement of operational safety of fishing vessels, (3) Fishing Boat Readiness Declaration Departing from the skipper (Master Sailing Declaration), and (4) Extension of SIPI / SIKPI fishing vessels.

\subsection{Factors That Cause Public Services at the Technical Implementation Unit of the Pondokdadap Coastal Fisheries Technical Port Not yet Professional and Quality}

Data related to factors that cause public services at UPT PPP Pondokdadap are not yet professional and quality obtained by researchers through the Strength, Weakness, Opportunities, and Threat (SWOT) analysis by interviewing methods to port experts and related experts as well as having been involved in the UPT PPP Pondokdadap for a long time. The inhibiting factors come from internal and external.

Internal factors that become obstacles in service at UPT Pondokdadap are, (1) The structure of the fleet used is classified as small/traditional with a low ability of science and technology causing poor handling of fish catches from ships, (2) Fishermen in catching fish do not heed the effectiveness and ecological balance, all fish are caught, the priority is more on the number of catches that are still dominated by small-sized fish, so that it is often questioned by foreign institutions, in this case, the IOTC (Indian Organization Tuna Commission) and is considered as the exploitation of fish that ignores sustainability. It is considered ecologically considered fishing irresponsible (Unresponsibility Fisheries), (3) The process of exporting tuna to Japan and Australia has experienced obstacles because it must pass through Surabaya, Banyuwangi, Jakarta and Bali which are highly dependent on the southern crossing path which has not been completed were built. Current route conditions, narrow roads, uphill and winding, rather difficult for large vehicles connected with UPT PPP Pondokdadap, (4) Insufficient land available for the development of port facilities to realize the Integrated Fishermen City Development Program (waterfront city) as part of UPT PPP Pondokdadap development plan to become an Indonesian Port that requires expansion of the Port area, (5) Lack of skilled Human Resources (HR) to deal with future developments and growth. Management HR is still inadequate with 23 people (1 person postgraduated (S2), 8 persons graduated (S1), while others have a high school, junior high and elementary school), (6) Does not function well with environmental control (cleanliness, security, order and pollution), so fishermen change oil and repair damaged ships by the beach. This can lead to pollution in coastal areas of Blue Spring, and (7) The absence of large companies engaged in tuna processing to support the sustainability of tuna fisheries carried out by smallscale fishermen.

External inhibiting factors are, (1) UPD PPP Pondokdadap which has main production in the form of important economic fish Tuna-Tuna-Cakalang (TTC) does not yet have a docking adequate ship, so that shipowners who wish to repair their fishing vessels, must be far away - far away to the Muncar Beach Fishing Port (Banyuwangi) or the Cilacap Archipelago Fisheries Port where the conditions of the area docking and equipment are adequate, (2) Lack of prime services related to the maintenance needs of operational facilities, both basic, functional and supporting facilities for ships and fishermen and stakeholders other conduct activities at UPT PPP Pondokdadap, (3) Fisheries business is still dominated by small fishermen and the use is based on temporary coastal waters and, (4) The low quality of human resources is seen from the average education level of fishermen which causes the technology and skills transfer process is not in accordance with expected, so that the impact there is a business development capability.

\subsection{Professional and Quality Public Service Models at Pondokdadap Coastal Fisheries Technical Implementation Unit}

The Public service models professional and quality at UPT PPP Pondokdadap are carried out by providing 
excellent service to the community, which is a manifestation of the obligations of the government apparatus as public servants. Types of services at UPT PPP Pondokdadap include, (1) public goods services in the form of aquaculture products, aquaculture/ capture fisheries processing products, marine products (non-consumption), and marine and fisheries research and development products, namely services that produce a variety of form / type of goods, (2) public services in the form of data and statistical services, fishery port services, fishery aquaculture services, marketing services, fishery product processing and marketing services, business capital management services, coastal community empowerment services, marine resource supervision services and fisheries, marine and fisheries development supervision services and community complaints management, research and development services, education and training services, fish quarantine services and fishery product quality testing, and (3) administrative services, namely administrative actions of ministries required by the state and regulated in statutory regulations in the field of marine and fisheries, in the form of licensing, certification and recommendations in the field of marine and fisheries.

The prime service model at the UPT PPP Pondokdadap fishery port is done through, (1) one-stop integrated service (PTSP), a public service pattern that is provided singly by a government work unit based on delegating authority from other relevant government work units concerned. This type of service pattern is one of institutional forms Whole of Government (WoG) the more complete, where public services are united in one service unit, and the permit chain has been cut into one. WoG is an approach to governance that unites the collaborative efforts of government from all sectors in a broader scope of coordination to achieve the objectives of policy development, program management and public services. With the One-Stop Integrated Service Model at UPT PPP Pondokdadap that informs each relevant agency and the services provided it will avoid fishermen queuing their documents at the wrong management table, thereby increasing the optimization of the document service process. In this service model, there are three agencies with their respective services, such as the Malang District PSDKP Satwas that serve the management of an Operation Worthiness Letter (SLO) and the Arrival/ Departure Inspection Results (HPK), Fisheries Syahbandar (KKP) who serve the Sailing Approval Letter (SPB), and UPT PPP Pondokdadap itself which serves the Proof of Arrival / Departure Report (STBLK), Fishing Certificate (SKPI), Fishing Catch Certificate (SHTI), and other services.

(2) Regional Public Service Board (BLUD) as an alternative to UPT PPP Pondokdadap management. The choice of this model is because the strategic position and direction of UPT PPP Pondok Pondok development are at the attractiveness and strength of high competition, so the appropriate development strategy is concentration through vertical integration. This strategy is following the position of UPT PPP Pondokdadap Malang which is in a very attractive industry, namely very high industrial attractiveness and internal business strength is a growth strategy with concentration through vertical integration using backward integration (by taking over functions supplier) or using forward integration (took over the distributor function). The results of research conducted by researchers indicate that UPT PPP Pondokdadap can be said to be ready if upgraded to BLUD status by looking at the factors of financial capacity, completeness of facilities and infrastructure as well as its potential, but supporting factors must be prepared in advance, especially in regulatory aspects that do not fully guarantee flexibility in its management, there are still many regulations both Provincial Regulations, Regional Regulations, Regency/ City Regulations and other regulations that hamper UPT PPP Pondokdadap to develop their potential, especially regarding the number of service tariffs and which synchronization has not yet been created which is the authority of the province and which is the authority of the district/city government city.

\section{DISCUSSION}

\subsection{Public Services at the Technical Implementation Unit of the Pondokdadap Beach Fisheries Port}

Public services at the Pondokdadap beach fishing port relate to the service of goods and services and administrative services which are all strongly influenced by the facilities, infrastructure and facilities available. Infrastructure facilities owned by UPT PPP Pondokdadap have met the criteria related to the facilities that must be owned by the fishing port in carrying out service activities and to be the only representative of a fishing port in East Java Province as a national fishery centre area, namely: (1) Has a mooring facility for fishing boats measuring at least 10 GT, (2) Having a pier length of at least $100 \mathrm{~m}$, with a depth of pond of at least minus $2 \mathrm{~m}$; and (3) Able to accommodate fishing vessels of at least 30 units or a total of at least $300 \mathrm{GT}$. This is by the Regulation of the Minister of Maritime Affairs and Fisheries No. 08/MEN/2012 concerning Fishery Ports Article 4 that in the framework of supporting the function of a fishing port, each fishing port has facilities: (a) basic facilities, (b) functional facilities, and (c) supporting facilities.

Capture fisheries business with fishing based in UPT PPP Pondokdadap Malang Regency is possible to run (from the operational aspect) because it is relatively close to the fishing ground. Also, facilities are available fishing-based that support because of the existence of PPP, available means of ice production and there is access to suppliers (suppliers) of the necessary factors of production, both for fuel, fishing equipment and supplies. The increasing fishing port activities caused Pondokdadap Coastal Fisheries Port to be determined by the Minister of Maritime Affairs and Fisheries as one of the locations for the development of national fisheries centres through 
Decree of the Minister of Maritime Affairs and Fisheries of the Republic of Indonesia Number 85 the Year 2016.

Goods and services at UPT PPP Pondokdadap are strongly influenced by basic, functional and supporting facilities that are owned, and based on the results of the analysis of the three facilities are complete and meet the criteria of this based on the Minister of Maritime Affairs and Fisheries Regulation Number. 08/MEN/2012 concerning Fisheries Seaport. With existing functional and supporting facilities, UPT PPP Pondokdadap, in addition to being able to carry out its main functions as a fishing port, such as providing mooring services, loading and unloading, repair and supplies of fishing vessels, processing services, marketing and distribution of fish, as well as service utilization facilities and land. UPT PPP Pondokdadap also innovates to develop the potential in the region with the concept of an eco fishing port, which is the concept of developing an environmentally friendly fishing port. Pondokdadap fishing port has an important role in encouraging the economic growth of the fishing community, supporting increased production, expediting fishing vessel traffic, implementing and controlling fish resources and accelerating service to all activities in the fishery sector.

Administrative services that are routinely carried out at UPT PPP Pondokdadap relating to business services, administration and community services include, management and issuance of a Fish Landing Certificate (SKPI), the function of martyrdom, and the extension of SIPI/SIKPI. The management and issuance of SKPI in UPD PPP Pondokdadap has been going well and has the support of relevant agencies, such as the Navy, Water Police, PSDKP and the Port of Pondokdadap. This is by the Governor Regulation No. 94 of 2008, Fisheries Maritime Regulation Number. 45 of 2015 concerning SLO (Operation Worthiness Letter), Fisheries Maritime Regulation Number. 36 of 2014 concerning andon fisheries, Maritime Fisheries Regulation Number. 13 of 2012 concerning certification of catches and the Director General's Regulation PSDKP No. 10 regarding technical instructions for verification of fish landings.

In 2017, the function of the Martyrdom Ship that runs at UPT PPP Pondokdadap is still not optimal, especially in the Issuance of Sailing Approval Letter (SPB) so that the Ministry of Maritime Affairs and Fisheries of the Republic of Indonesia places Syahbandar at the Pondokdadap Fishery Port of Malang, through Decree of the Director-General of Capture Fisheries Number: 77/KEP.JPT/2017 as amended Number: 13/KEP-DJPT/2018 Concerning the Placement and Assignment of the Airport at the Pondokdadap Beach Fishing Port. This has made the function of sharia in UPT PPP Pondokdadap increased and effective as evidenced by the implementation of the SHTI publishing service that has implemented ISO 9001: 2008 standard certification, namely the issuance of SHTI-LA. SHTI-LA is a Certificate of Catching Fish containing all catches made for each one time unloading activities for recording purposes.

The extension of SIPI / SIKPI at UPD PPP Pondokdadap has been going well, this is evidenced by the possession of Standard Operating Procedures (SOPs) and the effective implementation of the SOPs. UPT PPP Pondokdadap has also carried out a socialization mechanism for the Documentation and Licensing of Capture Fisheries Business to fishermen groups.

\subsection{Factors That Cause Public Services at the Technical Implementation Unit of the Pondokdadap Coastal Fisheries Technical Port Not yet Professional and Quality}

The factors that cause the unprofessional and quality UPT PPP Pondokdadap consist of internal and external factors. The weakness occurs because there are no facilities needed and the existing facilities do not meet the capacity, thus hampering operational activities. As for in detail internal factors that cause the unprofessional service at UPT PPP Pondokdadap namely, (1) The structure of the fleet that is used is classified as small/traditional with a low ability of science and technology causing poor handling of fish catches from ships, (2) Fishermen in catching fish Regardless of ecological effectiveness and balance, all fish are caught, and tend to quantity. This has been questioned by foreign institutions, namely the IOTC (Indian Organization Tuna Commission) and is considered a fish exploitation that disregards sustainability, so that it is considered ecologically irresponsible fishing (Unresponsibility Fisheries), (3) Export routes for marketing tuna fish to Japan and Australia is still under repair, thus hampering its distribution process, (4) Insufficient land available for the development of port facilities to realize the Integrated Fishermen Town Development Program (waterfront city) due to constrained land selection, namely owned by Perhutani, (5) Lack of skilled human resources for facing future developments and growth, that is only 23 people, (6) The function of environmental control (cleanliness, security, order and pollution) that has not been functioning properly, so that fishermen change oil and repair damaged vessels on the beach, if left unchecked continuously will tar so pollution in the coastal area of Sendang Biru, and (7) There are no large companies engaged in tuna processing to support the sustainability of the tuna fishing system that is carried out by small-scale PPP fishermen Pondokdadap.

External inhibiting factors are (1) Not having areas docking adequate ship, so that boat owners who wish to repair their fishing vessels must go to Muncar Beach Fishery Port (Banyuwangi) or Cilacap Nusantara Fisheries Port with adequate docking areas and equipment., (2) Lack of primacy of services related to the need for maintaining operational facilities, both basic, functional and supporting facilities for ships and fishermen and stakeholders other carrying out activities in PPP Pondokdadap, (3) Fishery business is still dominated by small 
fishermen and utilization that is based on water temporary beach, and (4) The low quality of human resources is seen from the level of fishermen's education which causes the process of transfer of technology and skills not as expected, thus affecting the ability of business development.

\subsection{Professional and Quality Public Service Models in the Pondokdadap Coastal Fisheries Technical Implementation Unit}

The professional and quality public service models at UPT PPP Pondokdadap can be realized through a one-stop service model with a flexible financial management pattern in the form of a Regional Public Service Agency (BLUD) so that it has the flexibility to implement sound business management practices such as productivity, efficiency and effectiveness, while at the same time maximizing the delivery of services to the community. This refers to Law Number 25 of 2009 concerning Public Services in article 1 point 1 which contains public services interpreted as activities or series of activities in the framework of meeting service needs by statutory regulations for each citizen and population of goods, services and/or administrative services organized by public service providers. The nature of public services is the provision of excellent service to the community, which is a manifestation of the obligations of government officials as public servants. Likewise, the fishing port as a public institution that also aims to provide the best service in meeting the interests of the fishing community.

UPT PPP Pondokdadap has performed the port service function by referring to the port function, namely the government function and the business function as in the Minister of Maritime Affairs and Fisheries Regulation Number. PER.08/ MEN/2012 concerning Fisheries and Ports. This relates to the performance in terms of operations and services provided by the fishing port to the perpetrators of activities so that the fishing port can work optimally. This is evidenced by already doing public goods services, public services and administrative services. The three types of public services at the fishing port are important because the fishing port is the main base of the capture fisheries industry activity which must guarantee the success of the capture fisheries business and encourage the development of the industry at the fishing port, not only on a local but regional and international scale. On an international scale, UPT PPP Pondokdadap already exports tuna fish to Japan and Australia. The success of the service is also supported by having port facilities, namely basic facilities, functional facilities, supporting facilities.

\section{CONCLUSIONS AND SUGGESTIONS}

\subsection{Conclusions}

At the level of applicable legislation, the public service at the Pondokdadap Coastal Fisheries Technical Implementation Unit has been adequate and meets the requirements in terms of availability of service facilities consisting of basic facilities, functional facilities, and supporting facilities. From the empirical conditions related to the factors that cause public services at UPT PPP Pondokdadap have not been professional and quality, namely: lack of quality and quantity of human resources, completeness of infrastructure including information technology, limited budget management and synergy of inter-institutional policies related to fisheries port management since the enactment of Law Number. 23/2014 concerning Regional Government. The professional and quality public service model at UPT PPP Pondokdadap can be realized through a one-stop service model with a flexible financial management pattern in the form of a Regional Public Service Agency (BLUD) so that it has the flexibility to implement sound business management practices such as productivity, efficiency, and effectiveness, while at the same time maximizing the implementation of services to the community.

\subsection{Recommendations}

On the aspect of resources, UPT PPP Pondokdadap requires assertiveness regarding the supply of resources, especially funds, and their allocation is consistent with the way of collaborative financing of fisheries port operations with relevant ministry agencies, local governments, communities and the private sector. In the organizational aspects of UPT PPP Pondokdadap, it is expected to be able to: (1) equip the personnel managing the UPT of the Pondokdadap Coastal Fisheries Port based on the structure, duties and functions of each, (2) Conduct a review of the human resources involved in the management of UPT PPP Pondokdadap, both in number and the capacity and qualifications of staff to fill assigned positions; and (3) Establish service standards that will provide information about service standards that must be set, institutions that support the implementation of services by established standards, and the quantity and competence of human resources needed and the distribution of service workloads to be handled. The Service model one stop that is applied at UPT PPP Pondokdadap should be guided by the following service principles: (1) Timeliness, (2) Accuracy, (3) Simplicity, (4) Clarity, (5) Security, (6) Openness, (7) Responsibility, (8) Completeness of facilities and infrastructure, (9) Convenience, (10) Discipline, (11) Courtesy and friendliness, and (12) Ease of access to services. Improving port services requires revitalization, improvement, maintenance and development of facilities from all relevant parties. 


\section{BIBLIOGRAPHY}

Akhyar Yusuf Lubis, 2014, Philosophy of Science, Classic to Contemporary, Jakarta, Raja Grafindo Perkasa. Andi Iqbal: Natsir Nessa: Andi Niartiningsih, 2013, Building Indonesian Marine Resources, Bogor, IPB Press. Bagong Suyanto, 2013, Social Research Methods Seventh Edition, Jakarta, Kencana Prenada Media Group.

Bambang Rudito, 2013, Social Mapping, Social Research Methods - Revised Edition, Bandung, Engineering Science.

Budi Winarno, 2014, Public Policy - Theory, Process and Case Studies, 2nd Printing, Yogyakarta, Center of Academic Publishing Service.

Burhan Bungin, 2013, Socio-Economic Research Methodology - Issue 1, Quantitative and Qualitative Formats for the Study of Sociology, Public Policy, Communication, Management, and Marketing, Jakarta: Prenanda Media Group.

Chaizi Nasucha, 2004, Public Administration Reform, Theory and Practice, Jakarta, Grasindo.

Deddy Mulyadi, 2015, Organizational Behavior and Service Leadership (Concepts and Applications of Modern Administration, Management and Organization), Bandung, Alfa Beta.

Ernani Lubis, 2012, Fisheries Port, Bogor, IPB Press.

Faisal Sanapiah, 1990, Qualitative Approach, Basics and Applications, Malang, Asih Asuh Foundation.

Haryatmoko, 2015, Public Ethics, For the Integrity of Public Officials and Politicians, Sleman, PT. Kanisius.

Harbani Pasolong, 2013, Public Administration Research Methods, Second Printing, Bandung, Alfabeta.

Hesti Puspitosari, 2016, Philosophy of Public Services, Jakarta, Equivalent Press

Ministry of Maritime Affairs and Fisheries of the Republic of Indonesia, 2009, Law Number 45 of 2009 concerning Fisheries of the

Ministry of Maritime Affairs and Fisheries of the Republic of Indonesia, 2009, Government Regulation of the Republic of Indonesia Number 61 of 2009 concerning Ports

Ministry of Maritime Affairs and Fisheries Republic of Indonesia, 2012, Regulation of the Minister of Maritime Affairs and Fisheries Number Per. 08 / Men / 2012 concerning Seaport of Fisheries of the

Ministry of Administrative Reform and Bureaucratic Reform of the Republic of Indonesia, 2009, Law Number 25 of 2009 concerning Public Services of the

Ministry of Administrative Reform and Bureaucratic Reform of the Republic of Indonesia, 2012, Government Regulation of the Republic of Indonesia Number 96 of 2012 concerning the Implementation of Law No. 25 of 2009 concerning Public Services of the

Ministry of Administrative Reform and Bureaucratic Reform of the Republic of Indonesia, 2012, Regulation of the Minister of Administrative Reform and Bureaucratic Reform of the Republic of Indonesia Number 36 of 2012 concerning Technical Guidelines for the Preparation, Establishment and Application of Service Standards.

Ministry of Administrative Reform and Bureaucratic Reform of the Republic of Indonesia, 2012, Regulation of the Minister of Administrative Reform and Bureaucratic Reform of the Republic of Indonesia Number 15 of 2014 concerning Guidelines for Service Standards.

Martin W. Bauer and George Gaskell, 2003, Qualitative Researching with Text, Image and Sound, London, SAGE Publication.

Norman Denzin, Yvonna Lincoln, 2009, Handbook of Qualitative Research, Yogyakarta, Student Library.

Malang Regency Government, 2009, Malang Regent Decree Number: 180/280 / Kep / 421.013 / 2009 concerning Sea Safety Team

Malang Regency Government, 2009, Malang Regency Regulation Number: 6 of 2016 concerning Malang Regency Medium-Term Regional Medium-Term Development Plan 2016 - 2021. 